\title{
Гидрометеорологические предпосылки
}

и геоморфологические последствия экстремального

паводка в бассейне малой реки в зоне влажных

субтропиков (на примере р. Цанык, район Сочи)*

\author{
А. С.Цыпленков ${ }^{1,2}$, Н. Н.Иванова ${ }^{1}$, Д. В. Ботавин ${ }^{1}$, \\ Ю. С. Кузнецова ${ }^{1,3}$, В. Н. Голосов ${ }^{1,2,4}$ \\ ${ }^{1}$ Московский государственный университет имени М. В. Ломоносова, \\ Российская Федерация, 119991, Москва, Ленинские горы, 1 \\ ${ }^{2}$ Институт географии Российской академии наук, \\ Российская Федерация, 119017, Москва, Старомонетный пер., 29 \\ ${ }^{3}$ Национальный исследовательский университет «Высшая школа экономики», \\ Российская Федерация, 109028, Москва, Покровский бул., 11 \\ ${ }^{4}$ Казанский (Приволжский) федеральный университет, \\ Российская Федерация, 420008, Казань, ул. Кремлевская, 18
}

Для цитирования: Цыпленков, А.С., Иванова, Н.Н., Ботавин, Д. В., Кузнецова, Ю.С., Голосов, В.Н. (2021). Гидрометеорологические предпосылки и геоморфологические последствия экстремального паводка в бассейне малой реки в зоне влажных субтропиков (на примере р. Цанык, район Сочи). Вестник Санкт-Петербургского университета. Науки о Земле, 66 (1), 144-166. https://doi.org/10.21638/spbu07.2021.109

Общее увеличение суммы осадков и усиление частоты выпадения экстремальных ливней подтверждается рядами метеорологических наблюдений как на Черноморском побережье Кавказа, так и в других регионах со сходными природными условиями. В связи с этим особую важность приобретают исследования факторов, способствующих превращению экстремального метеорологического события в экстремальный паводок и экстремальное геоморфологическое (эрозионное) событие. В статье анализируются факторы, приводящие к формированию внезапного (быстроразвивающегося, от англ. flashflood) паводка на водосборе р. Цанык (район Большого Сочи), и дается оценка его геоморфологических последствий. Анализ гидролого-метеорологической обстановки во время паводка на р. Цанык 7-9 сентября 2018 г. и в предшествующий период показал, что рассматриваемое событие с гидрологической точки зрения является уникальным для исследуемого водосбора. После продолжительного периода без осадков дожди, выпавшие 7-8 сентября, привели к формированию внезапного паводка с резким подъемом уровня воды (117 см за 40 мин). Темпы и объемы размыва русла определены на основе повторной тахеометрической съемки участка русла, оценки скорости размыва берегов, сложенных рыхлыми отложениями и коренными породами, производились методом шпилек с учетом протяженности каждого типа берегов. Объем размывов на бортах, сложенных рыхлыми отложениями, в среднем в 2-3 раза выше, чем на коренных бортах (флиш). При этом вынос материала за одно эрозионное событие

* Работа выполнена по госзаданию НИЛ эрозии почв и русловых процессов географического ф-та МГУ «Гидрология, морфодинамика и геоэкология эрозионно-русловых систем» (обзор исследований по ЧПК) и при финансовой поддержке РФФИ, проекты № 16-05-00815 (полевые работы и обработка результатов) и № 20-35-70035 (анализ результатов и подготовка текста).

(C) Санкт-Петербургский государственный университет, 2021 
сентября 2018 г. сопоставим (или даже превышает) суммарный объем размывов берегов за год, ранее выявленных на основе стационарных наблюдений.

Ключевые слова: сток наносов, внезапные паводки, экстремальные эрозионные события, субтропическая зона.

\section{1. Введение}

Дождевые осадки выпадают неравномерно как в пространстве, так и во времени. Асимметричность временного распределения подтверждается тем, что половина годовой суммы осадков выпадает в самые влажные 12 дней в году, в среднем на наблюдательных станциях по всему миру, а к 2100 году ожидается, что этот показатель будет равен 11 дням (Pendergrass and Knutti, 2018). Такие неблагоприятные прогнозы могут свидетельствовать о том, что повторяемость и интенсивность экстремальных событий со временем будет лишь возрастать.

Многие отмечают современную интенсификацию частоты и величины экстремальных гидрологических событий (ЭГС) на Северном Кавказе, связанную с текущими климатическими изменениями (Вишневская и др., 2016; Семенов и Коршунов, 2008; Rets and Kireeva, 2010). ЭГС на реках Северного Кавказа подробно исследованы в работах (Коронкевич и др., 2010; 2005; Болгов и Осипова, 2014; Магрицкий, 2014; Алексеевский и др., 2016; Вишневская и др., 2016), селевые явления в работах (Бондырев и Церетели, 2008; Мальнева и Кононова, 2012; Шныпарков и др., 2012). Исследованиям экстремальных эрозионных событий (ЭЭС) посвящены работы (Беркович и др., 2005; Голосов и др., 2012; Кузнецова и др., 2015; Иванова и др., 2018). Подробно изучены ЭЭС и зарубежными авторами, например в работе (Gaume et al., 2009) собраны сведения о 550 эрозионных событиях (ЭС). Обобщение этой информации позволило авторам установить, что наиболее экстремальные ЭС происходят в средиземноморских районах, преимущественно в осеннее время,

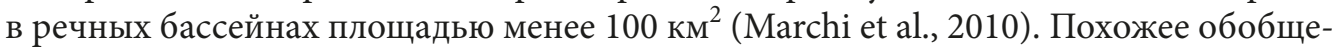
ние, но с упором на социально-экономический аспект, выполнено для территории США на основе анализа более 20000 событий, где также было установлено, что наиболее мощные ЭС приходятся на теплое время года (с мая по сентябрь) и наблюдаются в бассейнах с очень малой площадью, и при этом подвергается опасности наибольшее количество людей и хозяйственных объектов (Špitalar et al., 2014). Исследования различных факторов формирования эрозионных событий показывают, что наибольшая трансформация рельефа происходит при сочетании разных факторов редкой повторяемости, к примеру, при сочетании сильных ливневых дождевых осадков и града (Coppus and Imeson, 2002); прошедшего землетрясения и последующих сильных дождей (Tang et al., 2012).

Общее увеличение суммы осадков и усиление частоты выпадения экстремальных ливней подтверждается рядами метеорологических наблюдений как на Черноморском побережье Кавказа (ЧПК), так и в других регионах со сходными природными условиями. В связи с этим особую важность приобретают исследования факторов, способствующих превращению экстремального метеорологического события в экстремальный паводок и экстремальное геоморфологическое (эрозионное) событие. Для грамотного прогноза возможных геоморфологических последствий необходимо анализировать не только характеристики самого ме- 
теорологического события (продолжительность дождя, его интенсивность, площадь покрытия и т.д.), но и научиться оценивать факторы, влияющие на скорость добегания выпавшей на поверхность водосбора воды в русло реки, на соотношение слоя осадков и слоя поверхностного стока (часть выпавшей воды способна впитываться почвенно-грунтовыми толщами) и на степень насыщения поверхностного стока наносами. Предполагается, что немаловажную роль в инфильтрационной способности почвенно-грунтовых толщ во время экстремального ливня играют погодные особенности предшествующего паводку периода (длительное выпадение малоинтенсивных моросящих осадков или длительная засуха). Для оценки количества подготовленного для транспортировки сформировавшимся поверхностным стоком материала необходимо выявление источников бассейновых наносов, путей и темпов их перемещения со склонов в русло реки. Перечисленные факторы во многом определяют возможность формирования внезапных высоких паводков, несущих большое количество наносов, которые способны произвести значительную эрозионную работу и причинить существенный ущерб инфраструктуре, населенным пунктам и т.д.

Целью представленной статьи является анализ факторов, способствовавших формированию паводка на водосборе р. Цанык (район Большого Сочи), и оценка его геоморфологических последствий.

\section{2. Объект исследований}

Водосбор р. Цанык (правый приток р. Мацесты, рис. 1) по морфометрическим параметрам и степени антропогенной нагрузки - типичный речной бассейн предгорно-низкогорной зоны Черноморского побережья Кавказа. Длина реки 12.5 км, падение 572 м, площадь водосбора $\left(A\right.$, км$\left.^{2}\right)-11.7$ км². Подробная физико-географическая характеристика бассейна приведена в наших предыдущих работах (Иванова и др., 2018; Цыпленков и др., 2017). Поэтому здесь ограничимся описанием морфологии долины р. Цанык, которая во многом определяет коэффициент доставки склоновых наносов в русло реки во время эрозионных событий, а также степени и характера антропогенного воздействия.

Анализ карт и снимков разного масштаба, а также маршрутные описания позволили выделить четыре участка с различной интенсивностью антропогенной нагрузки и морфологией долины (см. рис. 2). Приустьевой отрезок долины (участок I) значительно трансформирован при строительстве эстакады объездной дороги (русло местами спрямлено и канализировано, днище долины завалено строительным мусором). Локально на пойменных участках присутствует дачная застройка. Выше по течению (примерно 2-6 км от устья) начинается сельскохозяйственнотрансформированный участок (участок II). Сужения долины с высокими складчатыми скальными обрывами чередуются с расширениями, где в недавнем прошлом были сельхозугодья (1980-1990-е гг.), а сейчас поверхность поймы занята дачнокоттеджной застройкой. Русло реки в пределах расширений искусственно спрямлено; уступы пойменных яров поддерживаются подпорными стенками из бетонных блоков, габионов, бетонных плит и подручного материала, которые при прохождении паводков часто разрушаются, что приводит к размывам.

Еще выше по течению (примерно 6-9 км от устья) начинается слабо преобразованный отрезок долины (участок III) в пределах Сочинского заказника. Долина 


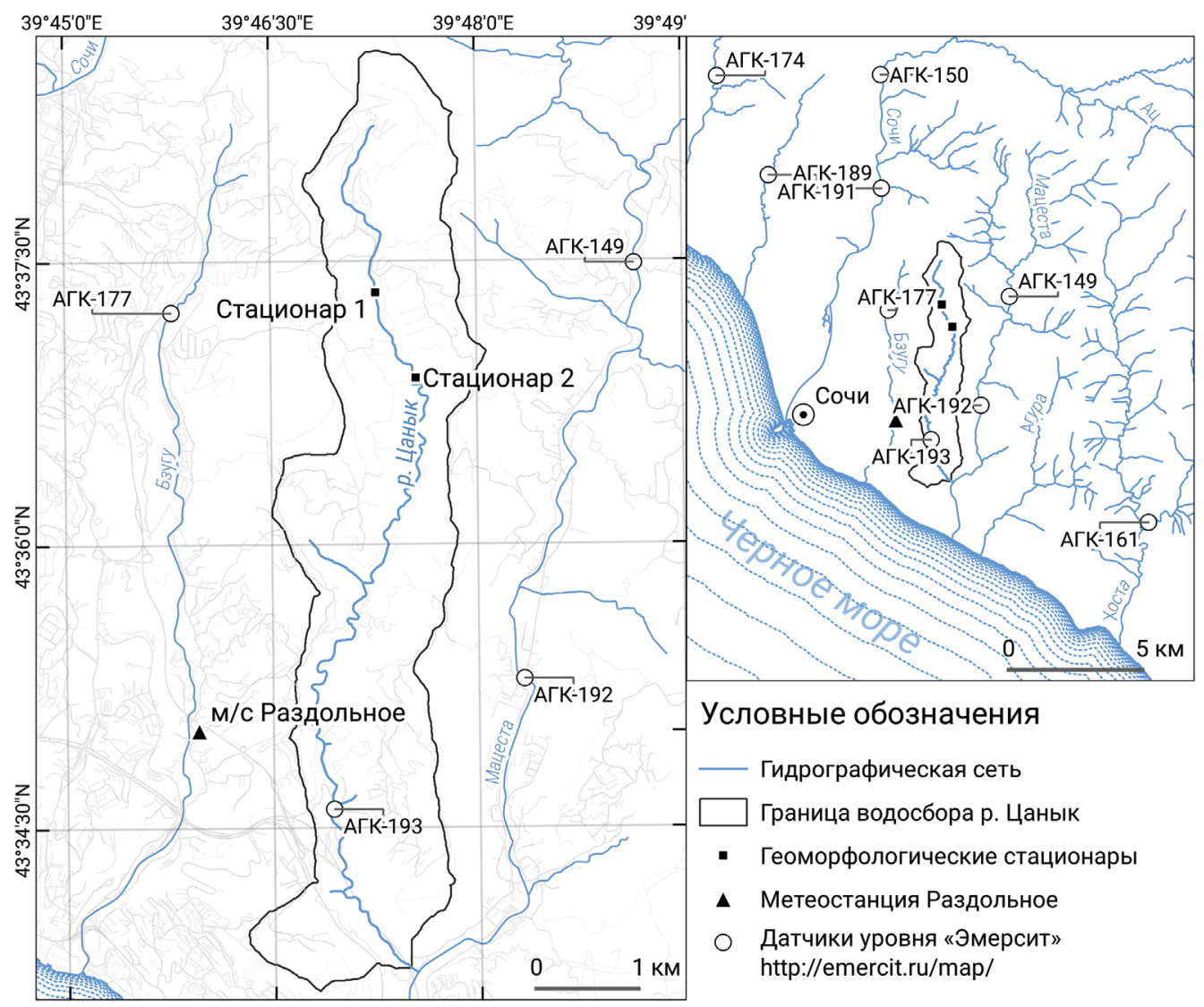

Puc. 1. Положение исследуемого водосбора. Все рисунки выполнены автором

р. Цанык здесь имеет корытообразную форму с крутыми бортами и пойменнотеррасовым комплексом в днище шириной 150-180 м. Склоны и днище долины заняты многоярусными колхидскими лесами. Русло развивается в естественных условиях, образуя серию вынужденных и адаптированных излучин. Сегменты поймы располагаются в шахматном порядке по обоим берегам, местами, несмотря на заповедный режим, они заняты дачными участками. Уклоны русла возрастают до $20-40 \%$, но в расширениях не превышают $15 \%$.

В верховьях р. Цанык (примерно 9-12 км от устья) по длине долины узкие $\mathrm{V}$-образные прямолинейные ущелья и каньоны с каскадными водопадами (высотой до 10 м) перемежаются расширениями (400-1000 м) с пологими склонами и низкой поймой, занятой селами и дачными поселками. Расширения приурочены к структурным ступеням с выходами плотных пород и эрозионным циркам. В расширениях русло образует серию крутых излучин, вогнутые берега которых интенсивно размываются. В верхнем течении уклоны русла возрастают до 20-40\%, но в расширениях не превышают $15 \%$.

Стационары для наблюдений за переформированием пойменно-руслового рельефа и интенсивностью овражной деятельности, а также станции мониторинга разрушения разных типов берегов расположены в пределах слабо преобразованного 


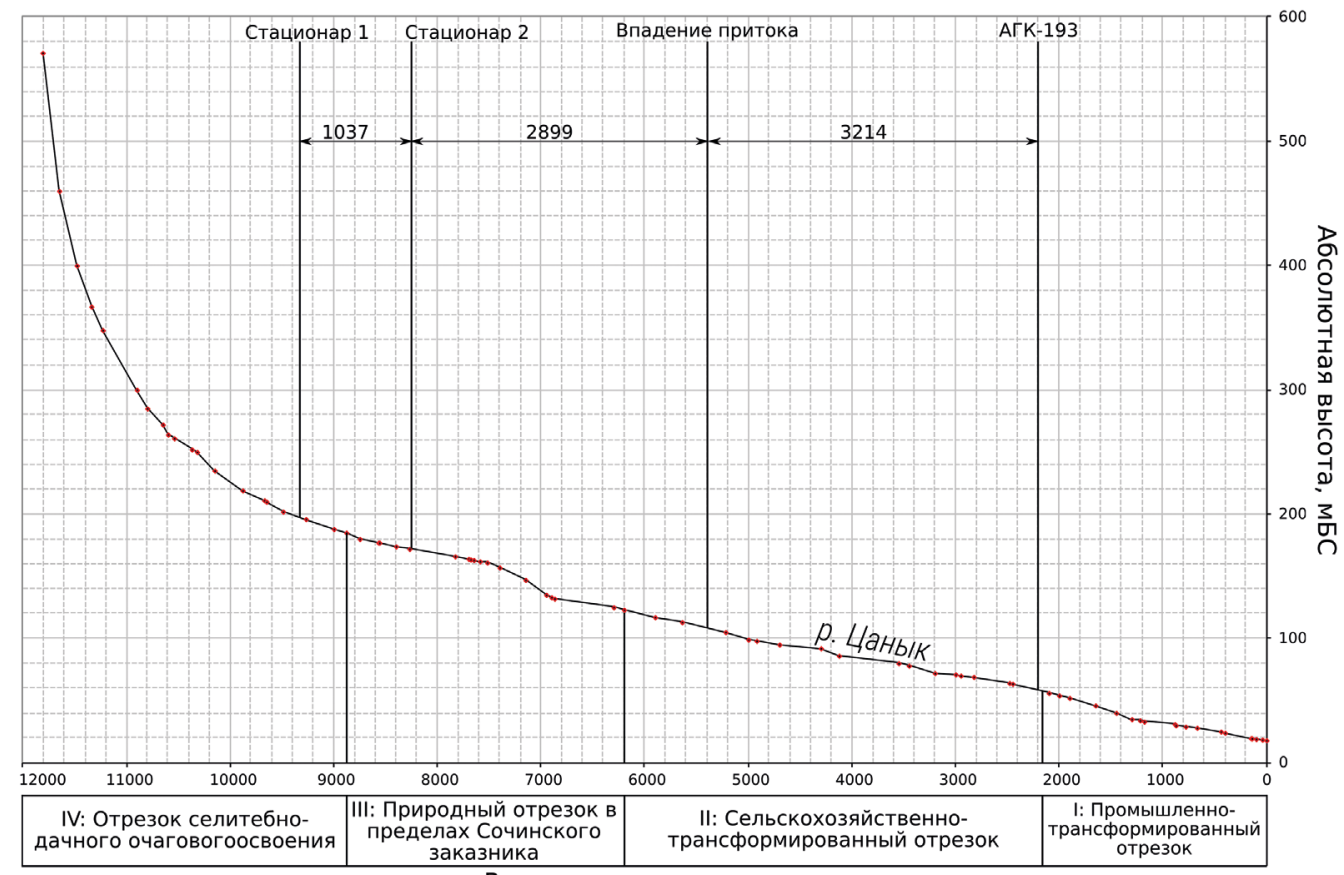

Расстояние от истока, м

Рuc. 2. Выделенные участки р. Цанык с различной интенсивностью антропогенной нагрузки и морфологией долины

антропогенной деятельностью отрезка долины р. Цанык на границе участков III и IV (см. рис. 2).

\section{3. Материалы и методы}

Оценка геоморфологических последствий единичного паводка на р. Цанык 7-9 сентября 2018 г. стала возможной исключительно потому, что на этом водном объекте в течение ряда лет авторами проводятся стационарные наблюдения за темпами размыва бортов и днища русла реки и характером проявления эрозионноаккумулятивных процессов на конусах выноса оврагов-притоков.

Комплекс используемых методов подробно описан в статье (Иванова и др., 2018). Мониторинг русловых размывов заключается в ежегодной съемке при помощи электронного тахеометра двух участков речных излучин (стационары 1,2 ) и прямолинейного отрезка русла, их соединяющего, а также в измерениях темпов отступания бортов русла, сложенных различными породами, на шести стационарных площадках с использованием метода шпилек. Также ежегодно отслеживается переформирование наложенного на пойму р. Цанык конуса выноса склонового оврага, где при помощи радиоцезиевого метода определены темпы аккумуляции за последние три десятилетия. Кроме того, периодически проводятся наблюдения за расходами воды и наносов, в том числе во время дождевых паводков. В начале сентября 2018 г. за два дня до паводка и сутками позже были проведены детальная съемка участка русла и поймы, расположенных между стационарами 1 и 2, и замеры шпилек на станциях мониторинга. 
Ниже более подробно описываются методы, на анализе результатов которых основано данное исследование.

\section{1. Изучение режима жидких осадков}

По данным метеостанции Раздольное, располагающейся на западном водораздельном хребте водосбора р. Цанык (см. рис. 1), были рассчитаны максимальные суточные осадки различной обеспеченности. Данные о температуре воздуха $\left(t,{ }^{\circ} \mathrm{C}\right)$ и количестве осадков $(x, \mathrm{~mm})$ были получены с временным разрешением в 12 часов для периода с 1966 по 2017 гг. из базы данных АИСОРИ (Булыгина и др., 2000), для 2018 г. - с сайта (rp5.ru, n. d.). Для разделения осадков на жидкие и твердые мы использовали граничное значение температуры воздуха в $+2{ }^{\circ} \mathrm{C}$ в соответствии с рекомендациями (Христофоров и др., 2015). Среднегодовое количество осадков в данном регионе составляет 1570 мм за более чем 100-летний период наблюдений (Цыпленков и др., 2017) по данным анализа суточных сумм осадков. При этом для периода 1957-2015 гг. среднегодовая сумма осадков равна 1630 мм. Проведенный в настоящей работе анализ 12-часовых данных осадков с 1966 по 2018 г. показал, что среднегодовая сумма осадков равняется 1525 мм ( $\delta=271$ мм), что на 100 мм меньше от приведенных ранее авторами (Цыпленков и др., 2017) значений. За 2018 г. выпало 1440 мм осадков (см. рис. 3), что меньше любого из приведенных среднегодовых значений.

Определенные методом моментов без поправок на смещение (Методические..., 2005) коэффициенты вариации $C v$ и асимметрии Cs равны 0.32 и 0.93 соответственно $(C s / C v=2.92)$ для ряда максимальных суточных осадков. В соответствии с рекомендациями (Клименко, 2017; Клименко и др., 2018) использовалось логнормальное распределение для построения эмпирической кривой обеспеченности (см. рис. 4). Также были определены максимальные «срочные» осадки, как максимальные значения, зафиксированные во время измерения на метеостанции за один срок. Учитывая 12-часовую дискретность данных и ливневой характер выпадения осадков в исследуемом регионе, данный подход кажется авторам единственным

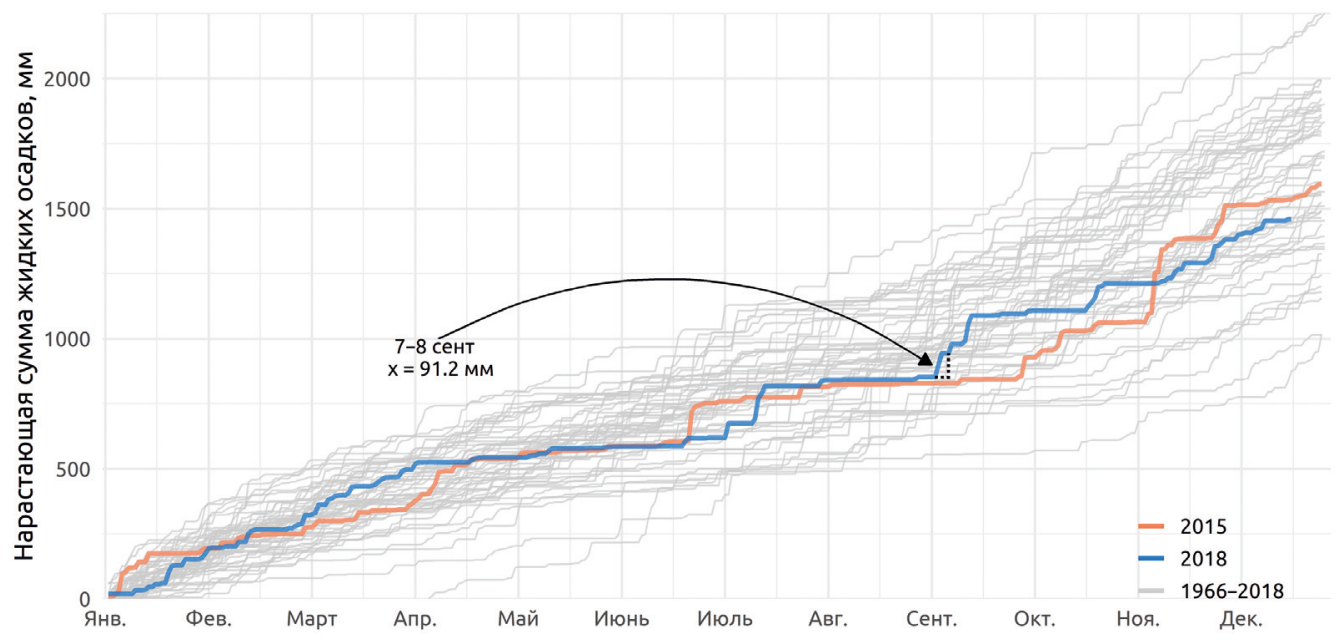

Рuc. 3. Годовые кумулятивные суммы осадков по м/с Раздольное с 1966 по 2018 г. 


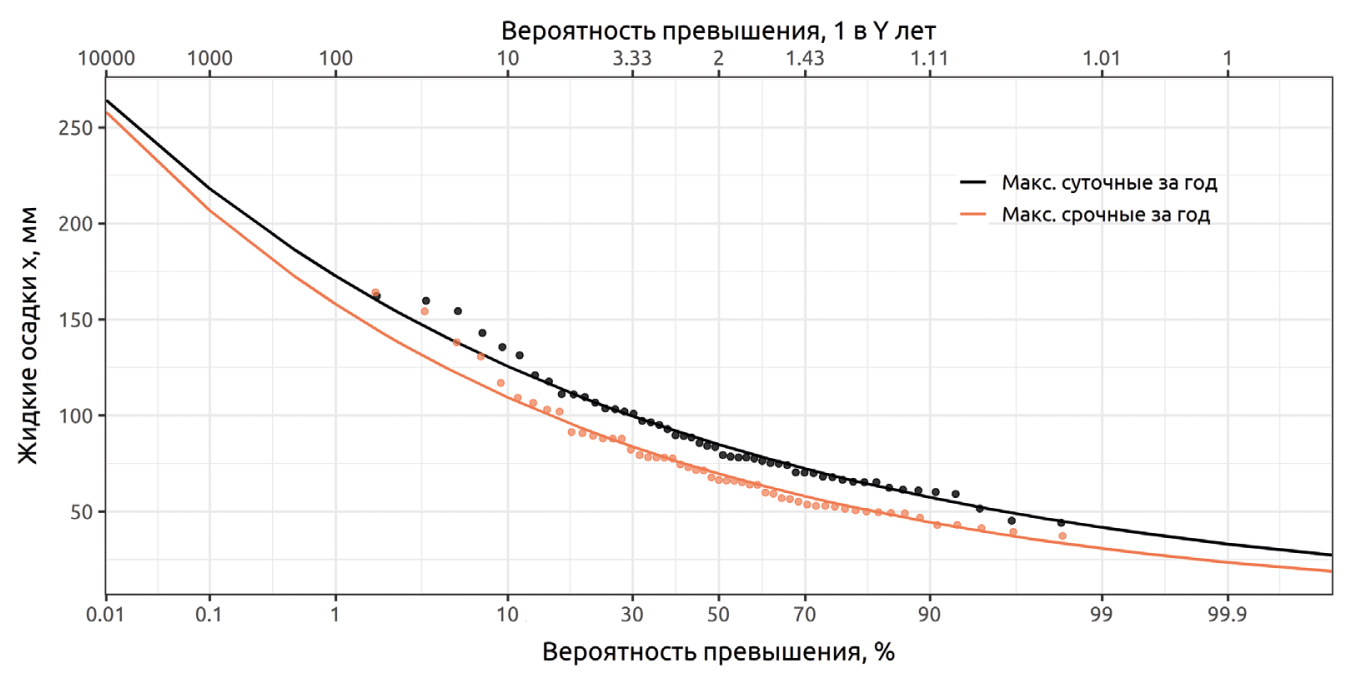

Puc. 4. Эмпирические (точки) и теоретические (линии) кривые распределения максимальных в году сумм осадков за сутки (черные точки и линия) и за срок наблюдения (красные точки и линия) для м/с Раздольное (1966-2018 гг.)

способом отследить по имеющимся данным экстремальные единичные ливни. Для ряда максимальных срочных осадков имеем $C v=0.39, C s=1.31, C s / C v=3.4$. При сравнимых величинах коэффициента вариации и $C s / C v$ коэффициент асимметрии для ряда срочных осадков в полтора раза выше, что указывает на смещение пика распределения в сторону меньших значений. Такая разница в Cs вызвана тем, что отдельные измерения осадков ожидаемо меньше, чем их дневные суммы.

\section{2. Изучение гидрологического режима}

Для анализа гидрологического режима р. Цанык использовались данные с автоматического уровнемера АГК-0193, входящего в автоматизированную систему мониторинга паводковой ситуации на реках Краснодарского края «Эмерсит» (emercit.ru, n. d.) (координаты датчика: $43.57661^{\circ}$ с. ш.; $39.7823^{\circ}$ в. д.). Результаты непрерывных уровенных наблюдений находятся в открытом доступе с 7 апреля 2014 г. с дискретностью в 10 мин и точностью определения уровня воды до 1 мм. Согласно информации, приведенной в справке к посту АГК-0193, уровнем неблагоприятного явления является 53.3 мБС, опасного явления - 53.6 мБС.

Учитывая конструктивные особенности данного датчика и частоту записи в 10 мин, временно́й ряд абсолютных отметок уровней воды насыщен аномальными точками, выбросами и шумами. Большинство существующих методик анализа временны́х рядов на выпадающие значения, выбросы или аномалии не подходит для анализа графиков хода уровня воды малых рек зоны влажных субтропиков, за счет особенностей их гидрологического режима. Вследствие резких и быстрых подъемов уровня воды (до 5-7 м), характерных для рек Черноморского побережья (Магрицкий, 2014), известные авторам статистические тесты (статистический критерий Шовене, тест Граббса, критерий Пирса, Q-тест Диксона) отклоняли нулевую гипотезу о том, что проверяемые значения не являются выбросами. В связи с этим 
удаление выпадающих точек, связанных с ошибками измерения, производилось вручную. В первую очередь, значения уровнемера округлялись до сантиметров. Согласно графоаналитическому анализу, не было зафиксировано действительного увеличения уровня за 10 мин более чем на 50 см. Таким образом, все значения, которые соответствуют росту уровня со скоростью большей, чем 50 см за 10 мин, принимались за выбросы и удалялись. Также записи уровня с 27.01.2016 4:40 по 27.01.2016 10:00, с 29.01.2017 21:20 по 01.02.2017 10:00, с 09.06.2017 10:00 по 09.06.2017 10:30, с 09.11.2017 10:20 по 09.11.2017 10:45, с 17.06.2018 18:30 по 18.06.2018 1:30 были визуально идентифицированы как некондиционные измерения и удалены. Пропущенные значения впоследствии интерполировались при помощи функции zoо::na. approx() из пакета zoo (Zeileis and Grothendieck, 2005) языка программирования R.

Определение гидрологических событий производилось в среде R. Для этого была написана функция, которая принимает на вход временной ряд уровней и период поиска минимальных значений. Разделение временного ряда на гидрологические события основано на графическом методе разделения гидрографа Б. Полякова (1946) и аналитическом методе (Sloto and Crouse, 1996), используемом USGS для разделения гидрографа на источники питания (https:/github.com/USGS-R/DVstats/ blob/master/R/hysep.R). Учитывая предыдущие исследования особенностей гидрологического режима рек Черноморского побережья России (Алексеевский и др., 2016; Магрицкий, 2014), локальные минимумы определялись за период 12 часов. Гидрологическим событием было принято считать отдельные паводки (штормовые события) (Тананаев, 2012), подъем уровня за которые был строго больше 5 см.

В соответствии с рекомендациями Государственного гидрологического института (Методические..., 2009) были определены максимальные расходы воды дождевых паводков обеспеченностью 1, 5, 10, 25 и 50 \% по редукционной формуле. Были выбраны две реки-аналога: р. Куапсе - Мамедова Щель и р. Псий - ТухАул, имеющие схожие морфометрические показатели водосбора $\left(F=14.6 \mathrm{kм}^{2}\right.$, $L=6.8$ км, $H_{\mathrm{cp}}=380$ м и $F=20.4 \mathrm{kм}^{2}, L=9.8$ км, $H_{\mathrm{cp}}=700$ м) и протекающие в тех же ландшафтно-климатических условиях. Информация о расходах воды разной обеспеченности была получена из (Алексеевский и др., 2016). Эти же данные легли в основу определения коэффициента редукции $\left(n_{1}\right)$ максимального стока с увеличением площади водосбора, который для ЧПК равен -0.75 , и определению переходных коэффициентов $\left(\lambda_{P}\right)$ от расходов воды ежегодной вероятности превышения $P=1 \%$ к более низким. Результаты расчета максимальных расходов воды приведены в табл. 1, максимальные расходы воды для р. Цанык определены как средние между расходами рек-аналогов.

Таблица 1. Расчетные максимальные расходы дождевых паводков в устье р. Цанык и слой максимальных суточных дождевых осадков

\begin{tabular}{|l|c|c|c|c|c|c|}
\hline \multirow{2}{*}{ Размерность } & \multicolumn{7}{|c|}{ Обеспеченность $P, \%$} \\
\cline { 2 - 7 } & $\mathbf{1}$ & $\mathbf{2}$ & $\mathbf{5}$ & $\mathbf{1 0}$ & $\mathbf{2 5}$ & $\mathbf{5 0}$ \\
\hline $\mathrm{Q}, \mathrm{M}^{3} / \mathrm{c}$ & 60 & 51.7 & 41 & 33 & 22.1 & 14 \\
\hline $\mathrm{X}_{\text {макс.сут. Мм }}$ & 177 & 162 & 142 & 126 & 104 & 84.8 \\
\hline $\mathrm{X}_{\text {макс.сроч., мм }}$ & 158 & 144 & 125 & 109 & 88.3 & 69.6 \\
\hline
\end{tabular}


Имеющаяся выборка гидрологических событий была сгруппирована в зависимости от продолжительности периода без осадков (с точностью до трех часов): 0-24 часа, 24-48 часа, 48-72 часа и больше 72 часов. Изменения уровня воды за гидрологическое событие $(\Delta h, \mathrm{M})$ рассчитывались как разница между максимальным и начальным уровнями воды за гидрологическое событие.

\section{3. Изучение переформирований пойменно-руслового рельефа р. Цанык при помощи повторной тахеометрической съемки}

Съемка рельефа местности на стационарах р. Цанык производилась с помощью электронного тахеометра Leica в условной прямоугольной системе координат с привязкой к реперной системе. Набор пикетов осуществлялся авторами с помощью вехи с отражателем. В процессе записи выделялось несколько классов пикетов: реперные точки, бровка, тыловой шов, русло, тальвег.

После получения данных происходила их первичная обработка в программном обеспечении Leica Geo Office и дальнейший экспорт в табличный формат «X, $\mathrm{Y}, \mathrm{Z}$ - координаты с высотой. Составление плана рельефа и последующий анализ производились в геоинформационной системе ESRI ArcGIS. Ввиду компактности участка и ограниченного количества съемочных пикетов, горизонтали отрисовывались в ручном режиме с шагом по высоте 0.2 м без применения автоматических интерполяционных методов создания цифровых моделей рельефа.

\section{4. Изучение темпов размыва бортов русла р. Цанык с использованием метода шпилек}

Для задач мониторинга размывов бортов русла был выбран участок среднего течения р. Цанык с наименьшим уровнем антропогенной нагрузки. Подробное описание данного метода приведено в статье (Kuznetsova et al., 2019).

Анализ данных детальной геоморфологической съемки русла и поймы р. Цанык позволил выделить основные типы бортов русла в зависимости от геологического строения, типа растительного покрова и преобладающих геоморфологических процессов на склонах долины: коренные склоны, сложенные флишевыми толщами (преимущественно переслаивание песчаников, аргиллитов и алевролитов), рыхлые борта двух типов (лишенные растительности и покрытые лесом) и уступы пойменно-террасового комплекса, сложенные рыхлыми отложениями (суглинками с включениями и прослоями обломков разной степени окатанности). На отрезке долины длиной 2.3 км в сентябре 2016 г. было заложено шесть станций для мониторинга динамики береговых уступов и активности русловых процессов. Станции характеризуют разные типы бортов русла и отличаются не только геологическим строением, но и ориентацией по отношению к оси русла. В качестве способа определения размывов мы использовали метод шпилек (Балян и Раменский, 1954; Goudie et al., 1990). На каждой станции перпендикулярно склону вбита сеть металлических реперов-шпилек, расположенных вертикальными рядами преимущественно в шахматном порядке. Расстояние между шпильками в среднем составляет 40-60 см (рис. 5). Такая густота позволяет минимизировать воздействие самого стационара на устойчивость уступа к размыву и склоновым процессам и при этом 

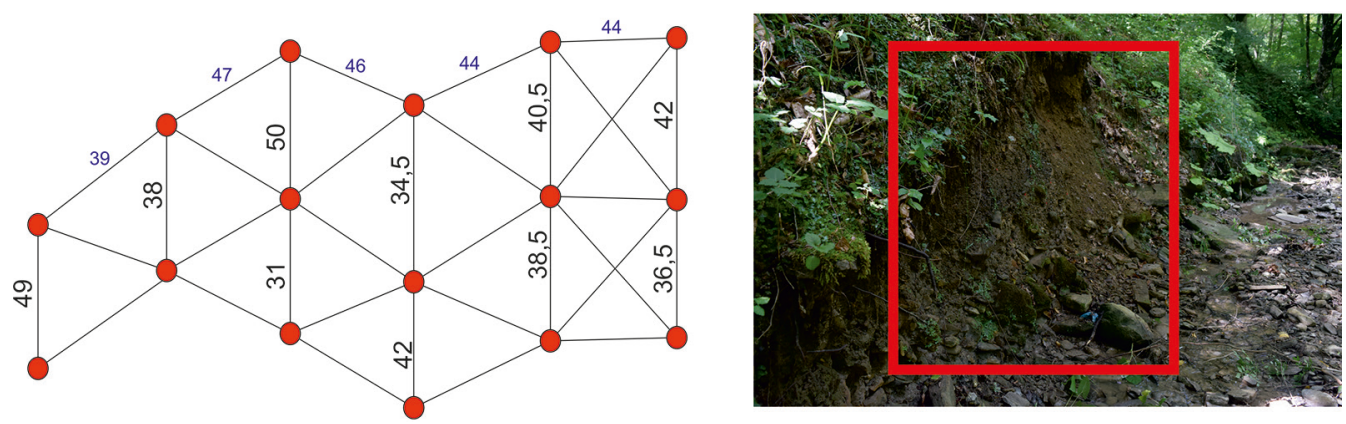

Puc. 5. Станция мониторинга размывов бортов русла р. Цанык ЦГ-04, схема расположения реперов-шпилек

максимально охватить измерениями представленные в стенке грунты, что особенно важно для слоистых рыхлых отложений уступов пойменных яров. Для каждой шпильки была измерена длина оголенной части (в скальные породы шпильки вбивались не на всю длину, чтобы не нарушить цельность берегового уступа).

Повторные измерения длины оголенных частей шпилек были проведены в сентябре 2017 г. и дважды в 2018 г. - 04.09.2018 и 09.09.2018, непосредственно до и сразу после исследуемого паводка. Это позволило количественно оценить изменения морфологии береговых уступов и рассчитать объемы вынесенного материала. Для перехода от объемных единиц к весовым осенью 2018 г. на каждой станции мониторинга были отобраны образцы для определения плотности слагающих подмываемые борта грунтов.

При обработке полученных данных для каждой станции мониторинга в ГИС Mapinfo были созданы карты расположения всех шпилек. На основании повторных исследований в программном пакете Surfer Golden Software для каждой даты измерений были построены цифровые модели микрорельефа и 3D-модели изменений морфологии береговых уступов.

\section{4. Результаты и обсуждение}

\section{1. Гидрометеорологическая обстановка 2018 г.}

В 2017 г. в течение 50 дней, а в 2018 г. на протяжении 46 дней выпадали стокоформирующие осадки, т.е. осадки, суточная сумма которых больше 10 мм. Однако эрозионных событий (за которые выпало более 12.7 мм осадков (Renard et al., 1997)) в 2018 г. было значительно меньше (23 события), чем в 2017 г. (34 события).

Анализ уровенных рядов за 2014-2018 гг. показал, что уровень воды на р. Цанык ни разу за эти 5 лет наблюдений не поднимался до отметки опасного или неблагоприятного явлений. Только в редких случаях уровень воды повышался более чем на 50 см - один раз в 2017 г. и четыре раза в 2018 г. Таким образом, исследуемый паводок 7-9 сентября 2018 г. является достаточно редким (насколько это позволяет судить имеющийся ряд наблюдений) по своей природе гидрологическим и эрозионным событием. Данный паводок был трехпиковым, и наш алгоритм разделения на гидрологические события выделил три отдельных события (рис. 6). 


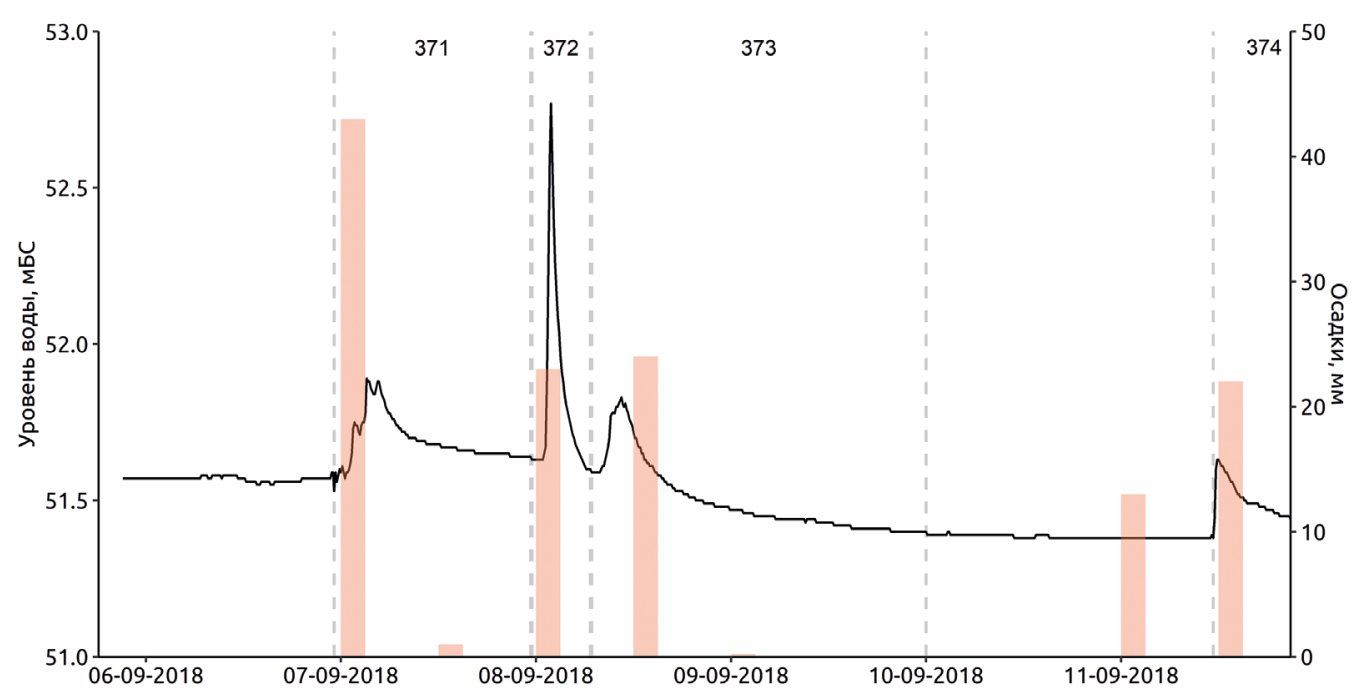

Puc. 6. Гидрологические события на р. Цанык осенью 2018 г.

За счет 43 мм осадков утром 7 сентября 2018 г. (со срока 6:00) уровень воды поднялся на 36 см. Выпавшие через день, утром 8 сентября 2018 г. (по данным срока в 6:00) осадки в 23 мм вызвали резкий подъем уровня на 117 см за 40 минут. При этом последующие 24 мм осадков, зафиксированные вечером 8 сентября (в 18:00), вызвали лишь 22-сантиметровый подъем уровня.

Мы предполагаем, что различия подъема уровня воды в зависимости от продолжительности предшествующего периода без осадков должны быть существенны и также важны при прогнозировании эрозионных и гидрологических событий. На это указывают проведенные ранее исследования по дождеванию в данном районе (Краснов, 1980), согласно которым коэффициент стока увеличивается более чем в два раза при выпадении дождя на подготовленную поверхность. Для подтверждения этого предположения мы проанализировали выборку гидрологических событий, вызванных только стокоформирующими осадками ( $x>10$ мм). Различия между изменениями уровня воды за гидрологическое событие в зависимости от периода без осадков были оценены при помощи рангового критерия Уилкоксона Манна - Уитни (табл. 2).

Таблица 2. Уровень статистической значимости ( для каждой из сравниваемых пар

\begin{tabular}{|l|c|c|c|}
\hline & $0-24$ ч & $24-48$ ч & $48-72$ ч \\
\hline $24-48$ ч & 0.99 & - & - \\
\hline $48-72$ ч & 0.59 & 0.59 & - \\
\hline больше 72 ч & 0.02 & 0.06 & 0.006 \\
\hline
\end{tabular}

Статистически значимая разница $(p<0.05)$ присутствует только если осадков не было более 72 часов, тогда как существенной разницы в парах «0-24 - 24-48», 


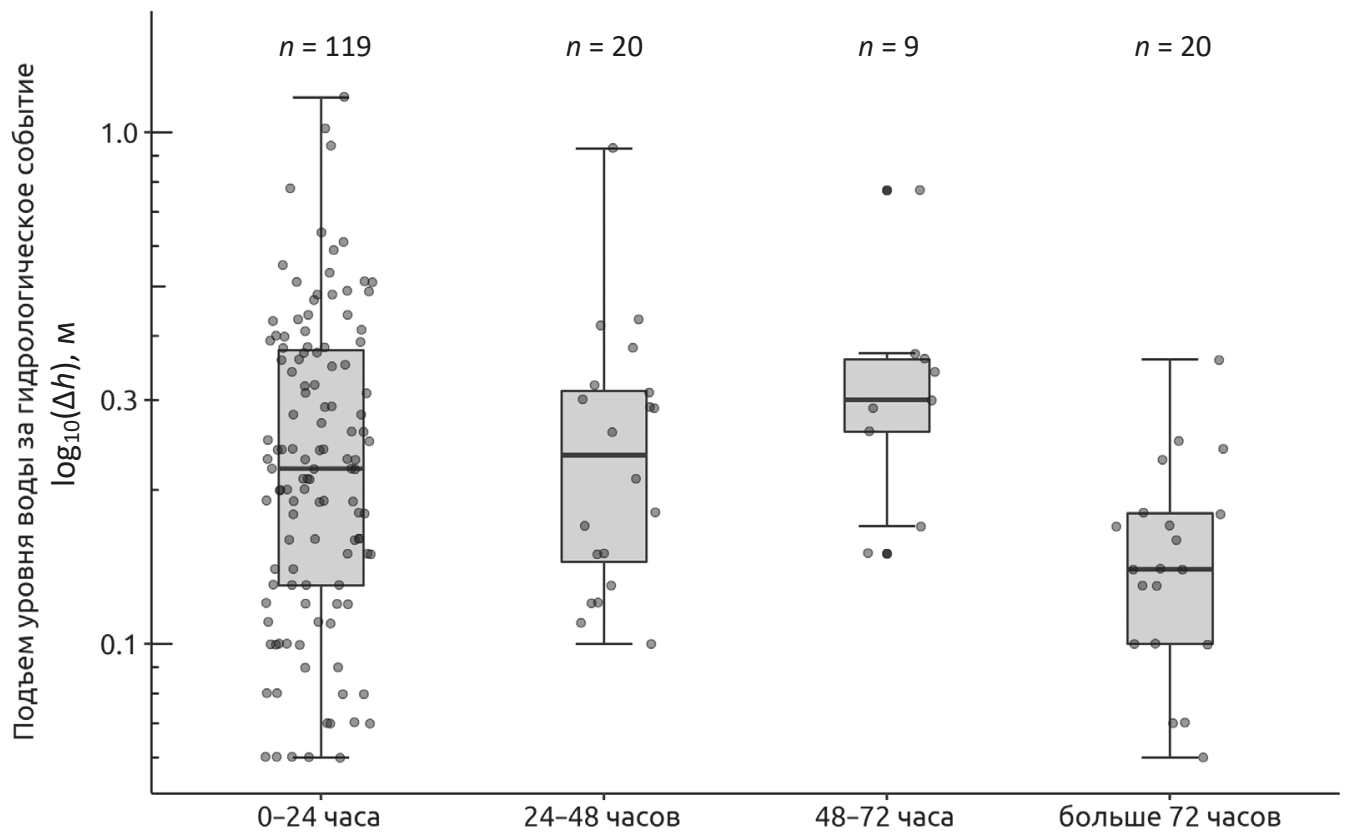

Puc. 7. Диаграмма размахов колебаний уровня воды за гидрологическое события 2014-2018 гг. на р. Цанык в зависимости от продолжительности периода без осадков. Количество событий ( $n$ ) указано над диаграммами размахов

«24-48 - 48-72» и «0-24-48-72» не наблюдается ( $p>0.05)$. Авторы использовали поправку Холма (Холма - Бонферрони) (Holm, 1979) для контроля над групповой вероятностью ошибки. В целом, полученные результаты согласуются с визуальной оценкой различий (рис. 7).

Коэффициент корреляции Спирмена между изменением уровня воды $(\Delta h, \mathrm{~m})$ и количеством осадков за гидрологическое событие ( $x$, мм) для всего ряда наблюдений составил $0.62(p<0.05)$. Однако в отдельные годы (см. рис. 8) коэффициент корреляции повышается до 0.88. Теснота корреляционной связи, вероятно, зависит от изменчивости охвата площади водосбора р. Цанык осадками со слоем, зафиксированным в точке наблюдений (на метеостанции). Временно́й характер выпадения осадков так же оказывает существенную роль на развитие паводковой волны. К сожалению, 12-часовые ряды осадков не позволяют сделать достоверных выводов, так как они дают возможность рассчитать лишь минимально возможную интенсивность дождя.

Таким образом, рассматриваемое эрозионное событие 8 сентября 2018 г. с гидрологической точки зрения является достаточно редким для данного водосбора. Резкий и высокий подъем уровня (1.17 м за 40 мин) за 5 лет наблюдений ранее зафиксирован не был. Более того, он был вызван осадками $99.9 \%$ обеспеченности (23 мм), выпавшими примерно через 24 часа после осадков $90 \%$ обеспеченности (43 мм). При этом осадки более низкой обеспеченности ( $25 \%$ и менее) не вызывали таких подъемов уровня на протяжении 5 лет наблюдений. 


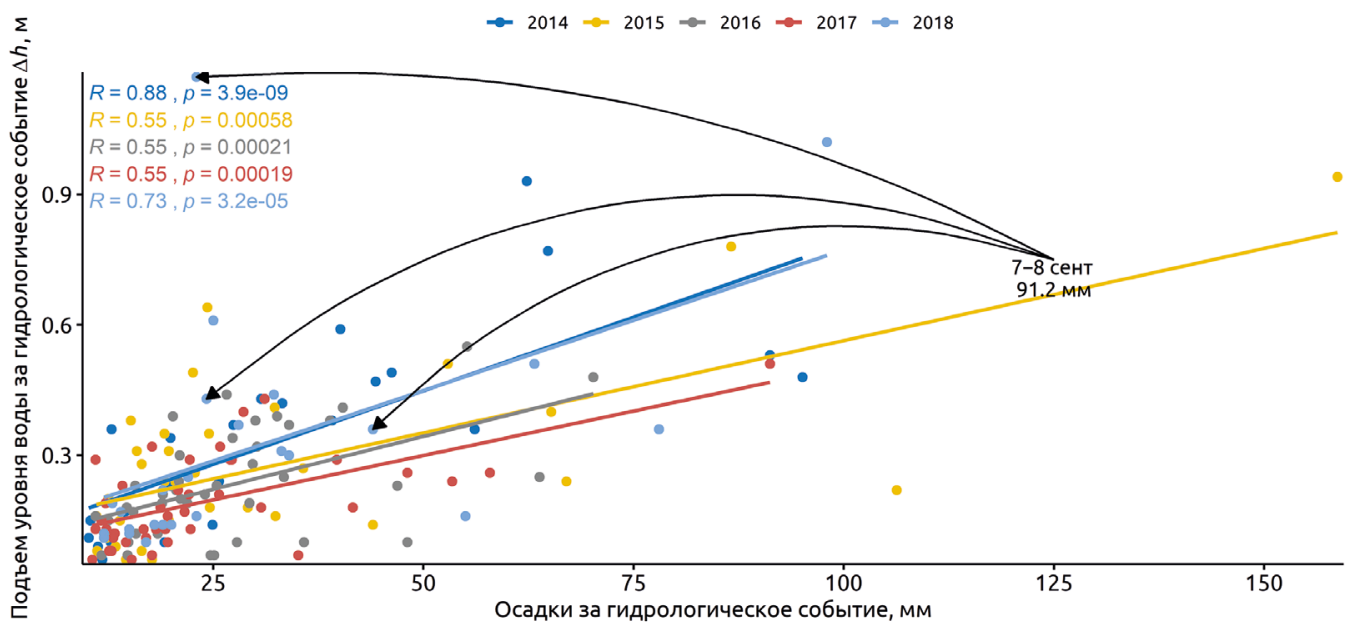

Puc. 8. Связь между подъемом уровня за гидрологическое событие $(\Delta h, \mathrm{M})$ и количеством жидких осадков за гидрологическое событие ( $x$, мм). Ось ординат логарифмическая. $R-$ коэффициент корреляции Спирмена, $p$ - уровень статистической значимости. На графике представлены только стокоформирующие осадки, $x<10$ мм

Таблища 3. Характеристика гидрометеорологической обстановки на реках региона

\begin{tabular}{|c|c|c|c|c|c|c|c|c|c|c|}
\hline \multirow[b]{2}{*}{$\begin{array}{l}\text { Дат- } \\
\text { чик }\end{array}$} & \multirow[b]{2}{*}{ Река } & \multirow[b]{2}{*}{ Пост } & \multirow[b]{2}{*}{$\begin{array}{c}A, \\
\mathbf{K M}^{2}\end{array}$} & \multirow{2}{*}{$\begin{array}{c}\text { Расст. } \\
\text { до } \\
\text { м/с, } \\
\text { км }\end{array}$} & \multicolumn{2}{|c|}{ Паводок 371} & \multicolumn{2}{|c|}{ Паводок 372} & \multicolumn{2}{|c|}{ Паводок 373} \\
\hline & & & & & Начало & $\begin{array}{c}\Delta h, \\
\mathbf{M}\end{array}$ & Начало & $\begin{array}{c}\Delta h, \\
\mathbf{M}\end{array}$ & Начало & $\begin{array}{c}\Delta h, \\
\mathbf{M}\end{array}$ \\
\hline $\begin{array}{l}\text { АГК- } \\
193\end{array}$ & Цанык & с. Раздольное & 11.7 & 1.53 & $\begin{array}{c}07.09 .2018 \\
3: 30\end{array}$ & 0.36 & $\begin{array}{c}08.09 .2018 \\
4: 10\end{array}$ & 1.17 & $\begin{array}{c}08.09 .2018 \\
11: 20\end{array}$ & 0.22 \\
\hline $\begin{array}{l}\text { АГК- } \\
192\end{array}$ & $\begin{array}{l}\text { Маце- } \\
\text { ста }\end{array}$ & $\begin{array}{l}\text { с. Краевско- } \\
\text { Армянское }\end{array}$ & 44.6 & 3.23 & $\begin{array}{c}07.09 .2018 \\
4: 20\end{array}$ & 0.51 & $\begin{array}{c}08.09 .2018 \\
4: 10\end{array}$ & 0.66 & $\begin{array}{c}08.09 .2018 \\
11: 00\end{array}$ & 0.12 \\
\hline $\begin{array}{l}\text { АГК- } \\
177\end{array}$ & Бзугу & с. Раздольное & 3.8 & 4.11 & $\begin{array}{c}\text { 07.09.2018 } \\
3: 00\end{array}$ & 0.73 & $\begin{array}{c}08.09 .2018 \\
3: 50\end{array}$ & 3.17 & $\begin{array}{c}08.09 .2018 \\
10: 00\end{array}$ & 0.46 \\
\hline $\begin{array}{l}\text { АГК- } \\
149\end{array}$ & $\begin{array}{l}\text { Маце- } \\
\text { ста }\end{array}$ & с. Измайловка & 28.8 & 6.27 & $\begin{array}{c}07.09 .2018 \\
3: 50\end{array}$ & 1.13 & $\begin{array}{c}08.09 .2018 \\
3: 50\end{array}$ & 1.52 & $\begin{array}{c}08.09 .2018 \\
10: 25\end{array}$ & 0.48 \\
\hline $\begin{array}{l}\text { АГК- } \\
189\end{array}$ & Сочи & $\begin{array}{l}\text { с. Пластунка } \\
\text { (низ) }\end{array}$ & 264 & 8.68 & $\begin{array}{c}07.09 .2018 \\
4: 10\end{array}$ & 2.22 & $\begin{array}{c}08.09 .2018 \\
3: 40\end{array}$ & 1.82 & $\begin{array}{c}08.09 .2018 \\
10: 00\end{array}$ & 1.14 \\
\hline $\begin{array}{l}\text { АГК- } \\
191\end{array}$ & Псахе & с. Васильевка & 8.86 & 10.34 & $\begin{array}{c}07.09 .2018 \\
1: 50\end{array}$ & 0.11 & $\begin{array}{c}08.09 .2018 \\
3: 40\end{array}$ & 0.49 & $\begin{array}{c}08.09 .2018 \\
9: 50\end{array}$ & 0.49 \\
\hline $\begin{array}{l}\text { АГК- } \\
150\end{array}$ & Сочи & $\begin{array}{l}\text { с. Пластунка } \\
\text { (верх) }\end{array}$ & 237 & 12.93 & $\begin{array}{c}07.09 .2018 \\
3: 30\end{array}$ & 1.71 & $\begin{array}{c}08.09 .2018 \\
3: 40\end{array}$ & 1.2 & $\begin{array}{c}08.09 .2018 \\
10: 40\end{array}$ & 0.8 \\
\hline
\end{tabular}

Примечание: Положение датчиков см. на рис. 1, характеристику паводков см. на рис. 6 и в тексте.

Данные изменения уровня воды на соседних реках (см. рис. 1 и табл. 3) позволяют проследить перемещение ядра дождя по водосборам 7-8 сентября 2018 г. в регионе. Быстрее всего реагирует датчик на р. Псахе, первый пик на ней начинается 7 сентября в 1:50 и вызывает небольшой подъем уровня на 11 см. Далее, пред- 
положительно, ядро дождя уходит на север, в долину р. Сочи (и север водосбора р. Мацесты) и лишь краем задевает водосборы рр. Бзугу и Цанык. На это указывает то, что подъем уровня на р. Сочи в 1.7-2.2 м был на 20-40\% выше, чем во время паводка на следующий день, в то время как на рр. Цанык и Бзугу (и Псахе) паводок 8 сентября, наоборот, на $\approx 70 \%$ выше, чем 7 сентября. Ночью 8 сентября ядро дождя также начинает продвигаться с северо-запада на юго-восток, но, в отличие от 7 сентября, не уходит вглубь материка, а остается в прибрежной части. На это указывает то, что максимальные подъемы за 7-8 сентября наблюдаются на рр. Цанык, Бзугу и Псахе, в то время как подъем уровня 8 сентября на р. Мацесте выше на 20\%, чем 7 сентября, а на р. Сочи ниже. Стоит отметить, что время начала паводка на всех датчиках примерно одинаковое и отличается на 10-20 мин. Утром 8 сентября основная масса осадков выпадает в северной и северно-западной частях региона. Например, на р. Псахе наблюдается такой же подъем уровня в 50 см, как и ночью, подъем уровня воды на р. Сочи лишь на 30 \% меньше, чем ночью. В то же время над водосборами рр. Бзугу, Цанык и Мацеста, видимо, выпадают осадки малой интенсивности, так как они приводят лишь к незначительным повышениям уровня воды (на $20 \%$ слабее, чем ночью).

Некоторые исследователи (Бондырев и Церетели, 2007) считают интенсивность осадков 50-80 мм/сут достаточной для образования селевого потока на всех водотоках, дренирующих горы Северного Кавказа. Нам кажется, что данное условие необходимо, но недостаточно даже для возникновения экстремального эрозионного события. Важна роль продолжительности предшествующего «сухого периода», т. е. времени без осадков. Проведенный дисперсионный анализ (см. табл. 2 и рис. 7) указывает на то, что статистически значимая разница подъемов уровня наблюдается только при отсутствии дождя более трех суток. Перед 7 сентября 2018 г. последние осадки, зафиксированные метеостанцией в Раздольном, выпали 1 сентября ( $x=8$ мм), т. е. за 140 часов до начала подъема уровня воды, а последние стокоформирующие осадки ( $x=20$ мм) были 3 августа, т. е. за 34 дня до паводка. Судя по всему, ключевую роль в образовании эрозионного события сыграло расположение ядра дождя и охват бассейна по площади этим дождем. На данном этапе исследования, по одной точке измерения слоя осадков, невозможно судить о фактическом максимальном слое, который выпал по площади всего бассейна за дождь в 23 мм. Другим фактором является интенсивность ливня, которая скорее всего превышала 1 мм/мин, что на фоне выпадения перед этим дождем ливня в 43 мм привело к очень быстрому сбросу воды со склонов в русло. Кроме того, сформировавшийся 8 сентября 2018 г. в русле р. Цанык поток не может быть отнесен к селевому, так как содержание твердого материала во фронтальной части не могло достигать 50-60 \% от массы воды.

\section{2. Оценка перебормирований пойменно-руслового рельеба р. Цанык на стационаре 1}

Сравнение результатов тахеометрических съемок днища долины на стационаре 1 до и после паводка 7-9 сентября 2018 г. показало, что это гидрологическое событие вызвало существенные изменения плановых очертаний бровки пойменного яра на каждой из излучин русла (рис. 9). 


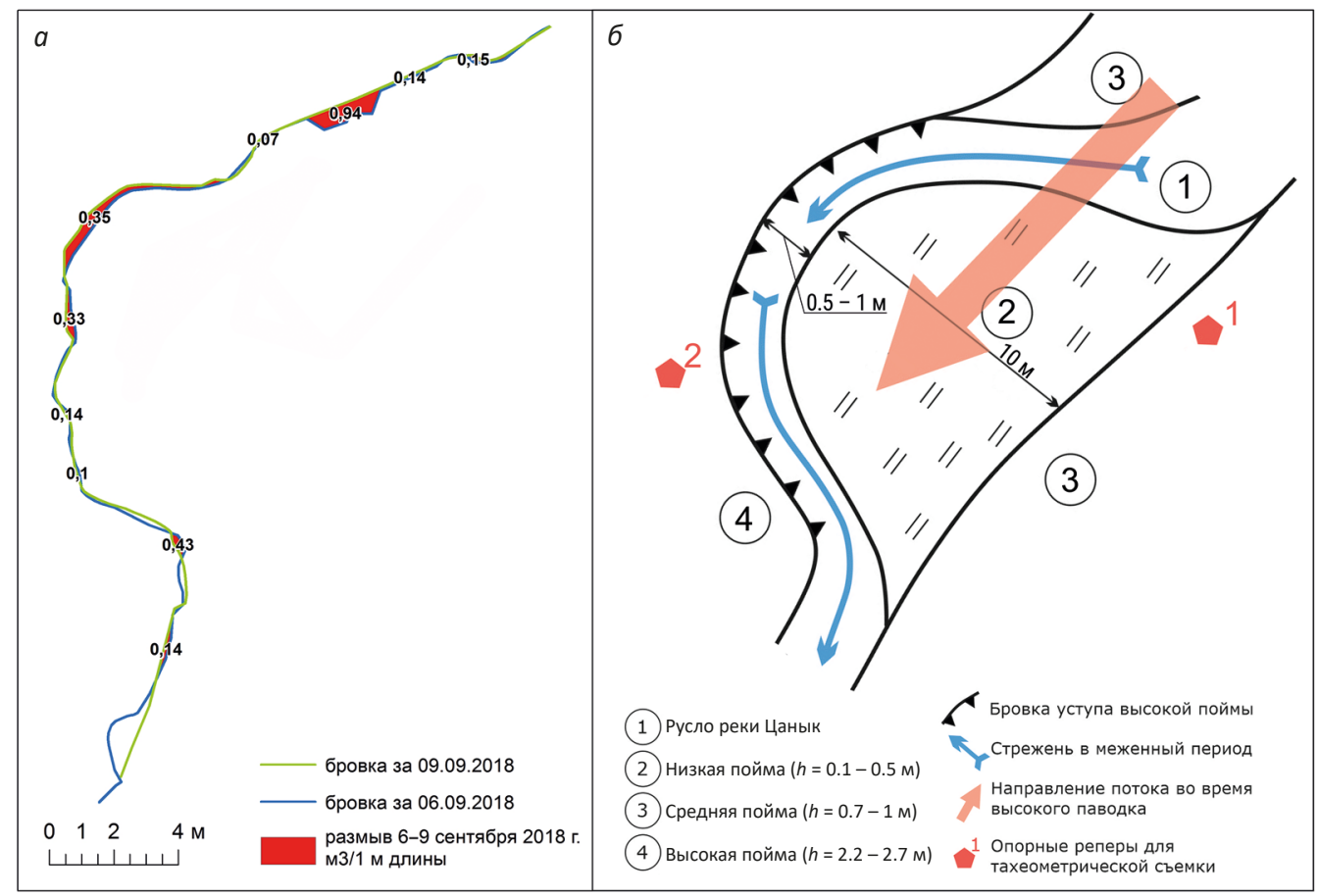

Puc. 9. Изменения плановых очертаний бровки пойменного яра правого борта р. Цанык в результате паводка 7-9 сентября 2018 г. для верхней (a) излучины на стационаре 1 (по результатам повторной тахеометрической съемки). План стационара 1 (б)

Максимальное зафиксированное отступание бровки составило 30-50 см, для большинства участков средние значения - 10-30 см. Были рассчитаны максимальный и средний объемы материала, вынесенного при разрушении уступа пойменного яра - 0.38 и $0.16 \mathrm{~m}^{3} / \mathrm{m}^{2}$ соответственно. Пойма р. Цанык в районе стационара 1 сложена легкими суглинками с многочисленными включениями обломков алевролитов и песчаников разного размера; вероятно, устойчивость к размыву примерно одинакова на всем протяжении исследованного участка. Можно предположить, что интенсивность размывов во многом определяется ориентацией уступа пойменного яра по отношению к оси паводочного потока.

Кроме того, на основе сопоставления планов прямолинейного участка русла, соединяющего верхнюю и нижнюю излучины, было установлено, что за счет массового перемещения донных наносов врезание русла составило 10 см. При этом перед нижней излучиной в русле сформировался осередок за счет переотложения глыб и крупной гальки разной степени окатанности. Переотложение валунно-галечного материала произошло в связи с резкой потерей мощности потока при фронтальном соударении с размываемым бортом.

\section{3. Оиенка размывов разных типов бортов русла р. Цанык по данным, полученным на станциях мониторинга}

Из шести станций мониторинга размывов бортов русла четыре заложены на уступах пойменных яров, сложенных рыхлыми отложениями аллювиального и, 
Таблица 4. Потери грунта в результате размывов бортов русла р. Цанык за разные интервалы времени

\begin{tabular}{|c|c|c|c|c|c|c|c|}
\hline \multirow{3}{*}{$\begin{array}{c}\text { Станция } \\
\text { мониторинга }\end{array}$} & \multirow{3}{*}{$\begin{array}{c}\text { Плотность } \\
\text { отложений, } \\
\text { т/м }{ }^{3}\end{array}$} & \multicolumn{6}{|c|}{ Потери грунта } \\
\hline & & \multicolumn{2}{|c|}{ 2016-2017 гг. } & \multicolumn{2}{|c|}{ 2017-2018 гг. } & \multicolumn{2}{|c|}{$\begin{array}{c}04.09 .2018- \\
09.09 .2018\end{array}$} \\
\hline & & $\mathrm{m}^{3} / \mathrm{M}^{2}$ & $\mathrm{~T} / \mathrm{M}^{2}$ & $M^{3} / M^{2}$ & $\mathrm{~T} / \mathrm{M}^{2}$ & $M^{3} / M^{2}$ & $\mathrm{~T} / \mathrm{M}^{2}$ \\
\hline \multirow[t]{3}{*}{ ЦГ-01 } & мин. 0.98 & \multirow[t]{3}{*}{0.027} & 0.027 & \multirow[t]{3}{*}{0.076} & 0.074 & \multirow[t]{3}{*}{0.1} & 0.098 \\
\hline & cp. 1.04 & & 0.029 & & 0.079 & & 0.104 \\
\hline & макс. 1.09 & & 0.030 & & 0.083 & & 0.109 \\
\hline \multirow[t]{3}{*}{ ЦГ-02 } & мин. 1.41 & \multirow[t]{3}{*}{0.009} & 0.013 & \multirow[t]{3}{*}{0.002} & 0.003 & \multirow[t]{3}{*}{0.028} & 0.040 \\
\hline & cp. 1.68 & & 0.015 & & 0.003 & & 0.047 \\
\hline & макс. 1.96 & & 0.018 & & 0.004 & & 0.055 \\
\hline \multirow[t]{3}{*}{ ЦГ-03 } & мин. 1.56 & \multirow[t]{3}{*}{0.032} & 0.050 & \multirow[t]{3}{*}{0.034} & 0.053 & \multirow[t]{3}{*}{0.045} & 0.070 \\
\hline & cp. 1.95 & & 0.062 & & 0.066 & & 0.088 \\
\hline & макс. 2.34 & & 0.075 & & 0.080 & & 0.105 \\
\hline \multirow[t]{3}{*}{ ЦГ-04 } & мин. 0.93 & \multirow[t]{3}{*}{0.03} & 0.028 & \multirow[t]{3}{*}{0.112} & 0.104 & \multirow[t]{3}{*}{0.020} & 0.019 \\
\hline & cp. 1.21 & & 0.036 & & 0.136 & & 0.024 \\
\hline & макс. 1.49 & & 0.045 & & 0.167 & & 0.030 \\
\hline \multirow[t]{3}{*}{ ЦГ-05 } & мин. 1.5 & \multirow[t]{3}{*}{0.042} & 0.063 & \multirow[t]{3}{*}{-} & - & \multirow[t]{3}{*}{-} & - \\
\hline & cp. 1.855 & & 0.078 & & - & & - \\
\hline & макс. 2.21 & & 0.093 & & - & & - \\
\hline \multirow{3}{*}{$\begin{array}{l}\text { ЦГ-06 (вариант 1) } \\
50 \text { \% песчаник, } \\
50 \text { \% рыхлый } \\
\text { заполнитель }\end{array}$} & песчаник 3.48 & \multirow[t]{3}{*}{0.041} & 0.071 & \multirow[t]{3}{*}{-} & - & \multirow[t]{3}{*}{0.014} & 0.024 \\
\hline & $\begin{array}{l}\text { рыхлый запол- } \\
\text { нитель } 1.53\end{array}$ & & 0.031 & & - & & 0.011 \\
\hline & & & Итог 0.103 & & - & & Итог 0.035 \\
\hline \multirow{3}{*}{$\begin{array}{l}\text { ЦГ-06 (вариант 2) } \\
50 \text { \% песчаник, } \\
50 \text { \% рыхлый } \\
\text { заполнитель }\end{array}$} & песчаник $2.72^{*}$ & \multirow[t]{3}{*}{0.041} & 0.056 & \multirow[t]{3}{*}{-} & - & 0.014 & 0.019 \\
\hline & $\begin{array}{l}\text { рыхлый запол- } \\
\text { нитель } 1.53\end{array}$ & & 0.031 & & - & & 0.011 \\
\hline & & & Итог 0.087 & & - & & $\begin{array}{l}\text { Итог } \\
0.030\end{array}$ \\
\hline
\end{tabular}

* Плотность песчаника взята как средняя по площадкам ЦГ-02 и ЦГ-06.

возможно, частично пролювиального генезиса. Плотность их значительно (в два и более раза) изменяется на разных площадках, что связано с различиями в гранулометрическом составе отложений и естественной вариабельностью упаковки слоев аллювия. В верховьях исследованного участка (станция ЦГ-01) грунты отличаются наименьшей плотностью (около 1 г/ $\mathrm{cm}^{3}$ ), здесь состав отложений достаточно грубый с хорошо выраженной горизонтальной слоистостью. Самые плотные грунты (около 2.2 г/ $\mathrm{cm}^{3}$ ) отмечены на станции ЦГ-05, где гранулометрический состав 
отложений более легкий, слоистость выражена очень слабо, количество включений крупных обломков минимальное. В табл. 4 записаны данные о потерях грунта (в объемных и весовых показателях) в результате размывов береговых уступов, полученные при обработке измерений шпилек за периоды 2016-2017 гг., 2017-2018 гг. и за одно эрозионное событие 7-9 сентября 2018 г.

Из представленных данных видно, что динамика размывов бортов русла отличается значительной пространственно-временной неоднородностью. Слишком короткий ряд наблюдений не позволяет провести статистический анализ, но на качественном уровне видно, что средние потери грунта (в объемных единицах) на станциях мониторинга, сложенных рыхлыми отложениями, в 2.5-3 раза выше, чем на коренных флишевых толщах. При этом объемы размывов, вызванных сильным паводком, сопоставимы, а в отдельных случаях значительно превышают полученные за два года наблюдений среднегодовые величины (табл. 5).

Таблица 5. Средние потери материала по станциям мониторинга с разным геологическим строением $\left(\mathrm{m}^{3} / \mathrm{m}^{2}\right)$

\begin{tabular}{|l|c|c|c|}
\hline \multirow{2}{*}{$\begin{array}{c}\text { Геологическое } \\
\text { строение }\end{array}$} & \multicolumn{3}{|c|}{ Период } \\
\cline { 2 - 4 } & $\mathbf{2 0 1 6 - 2 0 1 7 \text { гг. }}$ & 2017-2018 гг. & $\mathbf{0 4 . 0 9 . 2 0 1 8 - 0 6 . 0 9 . 2 0 1 8}$ \\
\hline Рыхлые отложения & 0.035 & 0.042 & 0.045 \\
\hline Флиш & 0.014 & 0.012 & 0.025 \\
\hline
\end{tabular}

Анализ динамики изменений уровня воды в р. Цанык за рассматриваемые периоды показал, что подъем уровня более, чем на 30 см в 2016-2017 гг. был зафиксирован 4 раза, а в 2017-2018 гг. - 9 раз, более, чем на 50 см - 1 и 4 раза соответственно. Возможно, это одна из причин увеличения средних потерь материала для бортов русла, сложенных рыхлыми отложениями.

Приведенные данные показывают, что рассчитанные по результатам замеров шпилек потери грунта во время эрозионного события с $1 \mathrm{~m}^{2}$ площади уступа пойменного яра на станции мониторинга ЦГ-01 $\left(0.1 \mathrm{~m}^{3} / \mathrm{M}^{2}\right.$, табл. 3) в несколько раз меньше, чем объем выноса, вычисленный по результатам повторной съемки бровки пойменного яра на стационаре $1\left(0.38 \mathrm{~m}^{3} / \mathrm{m}^{2}\right)$. Высота поймы и ее строение на этих участках достаточно похожи, поэтому полученные различия в темпах размыва можно объяснить тем, что исследованные уступы по-разному ориентированы относительно оси потока во время паводка, когда русловые отмели и осередки покрыты водой. Станция мониторинга ЦГ-01 расположена на относительно прямолинейном участке русла, а измеряемый уступ пойменного яра на стационаре 1 находится в нижней части крутой почти прямоугольной излучины фронтально относительно оси паводочного потока (рис. 2 и 9).

\section{5. Заключение}

Прослеживающаяся в последние годы тенденция увеличения как среднегодовой суммы осадков, так и числа значительных подъемов уровня воды рек Черноморского побережья Кавказа, зачастую сопровождающихся материальным ущер- 
бом и человеческими жертвами, ясно показывает необходимость изучения факторов формирования внезапных паводков.

Анализ гидролого-метеорологической обстановки во время паводка на р. Цанык 7-9 сентября 2018 г. и в предшествующий период показал, что рассматриваемое событие с гидрологической точки зрения является редким для исследуемого водосбора. Паводок был трехпиковым, и анализ гидрографа позволил выделить три отдельных гидрологических события.

По данным пятилетних наблюдений за уровнем на р. Цанык не было зафиксировано более резкого и высокого подъема уровня, чем во время этого паводка (1.17 м за 40 мин). Исследуемое гидрологическое событие произошло из-за дождя 99.9\% обеспеченности (23 мм), выпавшего примерно через сутки после ливня $90 \%$ обеспеченности (43 мм). Это обстоятельство заставляет предположить, что значительную роль в формировании внезапного паводка играют погодные условия предшествующего периода. Для проверки этого предположения был проведен анализ выборки гидрологических событий, вызванных только стокоформирующими осадками ( $x>10$ мм), сгруппированной в зависимости от продолжительности предшествующего периода без осадков. При помощи рангового критерия Уилкоксона - Манна - Уитни было доказано, что статистически значимая разница подъемов уровня воды есть только когда дождя не было более трех суток.

В условиях сильно расчлененного рельефа предгорно-низкогорного пояса, где расположен бассейн р. Цанык, характер выпадения осадков отличается крайней неравномерностью. Важное значение в формировании внезапного паводка имеет также расположение ядра конкретного ливня и охват территории бассейна осадками высокой интенсивности. Данные единственной метеостанции, расположенной на водоразделе рр. Цанык и Бзугу, не дают возможности достоверно оценить фактический максимальный слой осадков для всего водосбора.

Сравнение данных о размыве бортов русла р. Цанык во время исследуемого паводка с результатами мониторинга за два года показало существенную разницу в потерях грунта в результате разрушения береговых уступов в зависимости от геологического строения. Объем размывов на бортах, сложенных рыхлыми отложениями, в среднем в 2-3 раза выше, чем на коренных бортах (флиш). При этом вынос материала за одно эрозионное событие сентября 2018 г. сопоставим (или даже превышает) с суммарным объемом разрушений за год.

Результаты исследований геоморфологических последствий паводка на р. Цанык в сентябре 2018 г. показали важность регулярного мониторинга гидрологических и эрозионных процессов, а также необходимость расширения сети пунктов контроля за осадками и уровнями воды в реках Черноморского побережья Кавказа.

\section{Литература}

Алексеевский, Н.И., Магрицкий, Д. В., Колтерманн, П.К., Торопов, П. А., Школьный, Д. И., Белякова, П.А. (2016). Наводнения на черноморском побережье Краснодарского края. Водные ресурcbl, 43 (1), 3-17. https://doi.org/10.7868/S032105961601003X

Балян, Г. А. Раменский, Л. Г. (1954). О простейших способах учета смыва почв и определении их защебненности. Почвоведение, (2), 75-81.

Беркович, К. М., Голосов, В.Н., Зорина, Е.Ф., Коротаев, В.Н., Литвин, Л. Ф., Чалов Р. С. (2005). Эрозионно-русловые системы: структура и эволюция в условиях естественных и антропогенных изменений. Вестник Московского университета. Серия 5. Геограбия, (2), 61-67. 
Болгов, М. В., Осипова, Н. В. (2014). Совместный анализ данных по максимальному стоку и осадкам в бассейне реки Адагум. Водное хозяйство России: проблемы, технологии, управление, (3), 5-15.

Бондырев, И.В., Церетели, Э.Д. (2007). Катастрофические селевые потоки на юге Кавказа. В: Труды Международной научно-практич. конференции "Опасные природные и техногенные геологические процессы на горных и предгорных территориях Северного Кавказа». Владикавказ, 20-22 сентября 2007 г., Владикавказ: ВНЦ РАН и РСО-А, 108-115.

Булыгина, О. Н., Разуваев, В.Н., Коршунова, Н.Н., Швец, Н. В. (2020). Автоматизированная информационная система обработки режимной информации (АИСОРИ). [online] Доступно на: http:// aisori-m.meteo.ru/waisori/ [Дата доступа 26.02.2021].

Вишневская, И. А., Десинов, Л. В., Долгов, С. В., Коронкевич, Н. И., Шапоренко, С. И., Киреева, М. Б., Фролова, Н. Л., Рец, Е.П., Голубчиков, С.Н. (2016). Географо-гидрологическая оценка наводнений в Российском причерноморье. Известия Российской академии наук. Серия географическая, (1), 131-146. https://doi.org/10.15356/0373-2444-2016-1-131-146

Голосов, В.Н., Дела Сета, М., Ажигиров, А.А., Кузнецова, Ю.С., Дель Монте, М., Фреди, П., Лупия Пальмиери, Е., Григорьева, Т.М. (2012). Влияние антропогенной деятельности на интенсивность экзогенных процессов в низкогорьях субтропического пояса. Геоморбология, (2), 7-17. https://doi.org/10.15356/0435-4281-2012-2-7-17

Иванова, Н.Н., Голосов, В.Н., Цыпленков, А. С., Кузнецова, Ю. С., Ботавин, Д. В. (2018). Источники бассейновой составляющей стока наносов малой реки низкогорно-предгорного пояса Черноморского побережья Кавказа (на примере р. Цанык). Инженерные изыскания, 12 (7-8), 62-76. https://doi.org/10.25296/1997-8650-2018-12-7-8-62-74

Клименко, Д.Е. (2017). Опыт применения односторонне-усеченного лог-нормального распределения к расчетам максимального стока дождевых паводков на малых реках. Инженерные изыскания, (10), 66-71. https://doi.org/10.25296/1997-8650-2017-10-66-71

Клименко, Д.Е., Черепанова, Е.С., Габова, Л.В., Щапова, И.В. (2018). Сравнительный статистический анализ данных наблюдений осадкомеров и плювиографов для оценки характеристик паводкоформирующих осадков на территории Урала. Метеорология и гидрология, (8), 91-99.

Коронкевич, Н.И., Барабанова, Е.А., Бумакова, А.Ф., Зайцева, И.С., Малик, Л. К. (2005). Экстремальные гидрологические явления. Известия Российской академии наук. Серия геограбическая, (2), 45-57.

Коронкевич, Н.И., Барабанова, Е.А., Зайцева, И.С. (2010). Экстремальные гидрологические ситуаици. Москва: Медиа-ПРЕСС.

Краснов, С.Ф. (1980). Изучения смыва почв методом искусственного дождевания. В: Эрозия почв и освоение склоновых земель в субтропической зоне РСФСР. Научн. труды НИГСиЦ, Т. 27. Сочи: НИИГСиЦ Сочи, 97-104.

Кузнецова, Ю.С., Голосов, В.Н., Куксина, Л.В. (2015). Внезапные паводки: факторы формирования, распространение и методы прогнозирования. В: Проблемы прогнозирования чрезвычайных ситуаций. Круглый стол. 17 сентября 2015 г. Доклады и выступления. Москва: ФКУ Центр «Антистихия» МЧС России, 207-214.

Магрицкий, Д.В. (2014). Пространственно-временные характеристики наводнений на Черноморском побережье Российской Федерации. Вестник Московского университета. Серия 5. География, (6), 39-47.

Мальнева, И. В., Кононова, Н. К. (2012). Активность селей на территории России и ближнего зарубежья в XXI веке. Геориск, (4), 48-54.

Методические рекомендаиии по определению расчетньх гидрологических характеристик при наличии данных гидрометрических наблюдений. (2005). Санкт-Петербург: ГГИ.

Методические рекомендащии по определению расчетных гидрологических характеристик при отсутствии данных гидрометрических наблюдений. (2009). Санкт-Петербург: Нестор-История.

Поляков, Б.В. (1946). Гидрологический анализ и расчеть: Учебное пособие. Ленинград: Гидрометеоиздат.

Семенов, В.А., Коршунов, А.А. (2008). Районирование территории России по опасности высоких наводнений в связи с изменениями климата. Использование и охрана природных ресурсов в России, (5), 58-61.

Тананаев, Н.И. (2012). Эффект гистерезиса в сезонной изменчивости соотношения расхода и мутности воды рек криолитозоны Сибири и Дальнего Востока. Водные ресурсы, (6), 598-607. 
Христофоров, А. В., Юмина, Н. М., Белякова, П. А. (2015). Прогноз паводкового стока рек Черноморского побережья Кавказа с заблаговременностью одни сутки. Вестник Московского университета. Серия 5. География, (3), 50-57.

Цыпленков, А. С., Голосов, В. Н., Куксина, Л. В. (2017). Оценка бассейновой составляющей стока взвешенных наносов в малых речных бассейнах сухих и влажных субтропиков при экстремальном стоке. Инженерные изыскания, (9), 54-65. https://doi.org/10.25296/1997-8650-2017-9-54-65

Шныпарков, А. Л., Колтерманн, К. П., Селиверстов, Ю. Г., Сократов, С. А., Перов, В. Ф. (2012). Селевой риск на Черноморском побережье Кавказа. Геориск, (4), 20-25.

Coppus, R. and Imeson, A.C. (2002). Extreme events controlling erosion and sediment transport in a semi-arid sub-andean valley. Earth Surface Processes and Landforms, 27 (13), 1365-1375. https://doi. org/10.1002/esp.435

emercit.ru. (n.d.). Система мониторинга «Эмерсит». [online] Доступно на: http://emercit.ru/ map/ [Дата доступа 19.02.2021].

Gaume, E. et al. (2009). A compilation of data on European flash floods. Journal of Hydrology, 367 (1-2), 70-78. https://doi.org/10.1016/j.jhydrol.2008.12.028

Goudie, A., Lewin, J., Richards, K., Anderson, M., Burt, T., Whalley, B. and Worsley, P. (1990). Geomorphological Techniques. London: Unwin Hyman.

Holm, S. (1979). A Simple Sequentially Rejective Multiple Test Procedure. Scandinavian Journal of Statistics, $6(2), 65-70$.

Kuznetsova, Yu., Golosov, V., Tsyplenkov, A. and Ivanova, N. (2019). Quantifying channel bank erosion of a small mountain river in Russian wet subtropics using erosion pins. Proc. Int. Assoc. Hydrol. Sci., 381, 79-86. https://doi.org/10.5194/piahs-381-79-2019

Marchi, L., Borga, M., Preciso, E. and Gaume, E. (2010). Characterisation of selected extreme flash floods in Europe and implications for flood risk management. Journal of Hydrology, 394 (1-2), 118-133. https:// doi.org/10.1016/j.jhydrol.2010.07.017

Pendergrass, A. G. and Knutti, R. (2018). The uneven nature of daily precipitation and its change. Geophysical Research Letters, 45 (21), 11,980-11,988. https://doi.org/10.1029/2018GL080298

Renard, K. G., Foster, G. R., Weesies, G. A., McCool, D. K. and Yoder, D. C. (1997). Predicting soil erosion by water: a guide to conservation planning with the Revised Universal Soil Loss Equation (RUSLE). In: Agricultural Handbook No. 703, 65-100.

Rets, E. and Kireeva, M. (2010). Hazardous hydrological processes in mountainous areas under the impact of recent climate change: case study of Terek River basin. In: Global Change: Facing Risks and Threats to Water Resources. IAHS Publ., 126-134.

rp5.ru. (n. d.). Расписание погоды. [online] Доступно на: https://rp5.ru/ [Дата доступа 19.02.2021].

Sloto, R. A. and Crouse, M. Y. (1996). Hysep: a computer program for streamflow hydrograph separation and analysis. U.S. Geological Survey Water-Resources Investigations Report 96-4040.

Špitalar, M., Gourley, J. J., Lutoff, C., Kirstetter, P.-E., Brilly, M. and Carr, N. (2014). Analysis of flash flood parameters and human impacts in the US from 2006 to 2012. Journal of Hydrology, 519, 863-870. https://doi.org/10.1016/j.jhydrol.2014.07.004

Tang, C., van Asch, T. W. J., Chang, M., Chen, G. Q., Zhao, X. H. and Huang, X. C. (2012). Catastrophic debris flows on 13 August 2010 in the Qingping area, southwestern China: The combined effects of a strong earthquake and subsequent rainstorms. Geomorphology, 139-140, 559-576. https://doi.org/10.1016/j. geomorph.2011.12.021

Zeileis, A. and Grothendieck, G. (2005). zoo: S3 Infrastructure for Regular and Irregular Time Series. Journal of Statistical Software, 14 (6). https://doi.org/10.18637/jss.v014.i06

Статья поступила в редакцию 22 мая 2020 г. Статья рекомендована к печати 14 декабря 2020 г.

Контактная информация:

Цыпленков Анатолий Сергеевич — atsyplenkov@gmail.com

Иванова Надежда Николаевна - nadine_iv@mail.ru

Ботавин Дмитрий Викторович - dmitry.botavin@gmail.com 
Кузнеиова Юлия Сергеевна - kuzyulia@gmail.com

Голосов Валентин Николаевич — gollossov@gmail.com

\title{
Hydro-meteorological preconditions and geomorphological consequences of extreme flood in the small river basin in the wet subtropical zone (the Tsanyk River case study, Sochi region)*
}

\author{
A. S. Tsyplenkov $v^{1,2}$, N. N. Ivanova ${ }^{1}$, D. V.Botavin ${ }^{1}$, Yu. S. Kuznetsova ${ }^{1,3}$, V. N. Golosov ${ }^{1,2,4}$ \\ ${ }^{1}$ Lomonosov Moscow State University, \\ 1, Leninskie Gory, Moscow, 119991, Russian Federation \\ 2 Institute of Geography of the Russian Academy of Sciences, \\ 29, Staromonetniy per., Moscow, 119017, Russian Federation \\ ${ }^{3}$ Higher School of Economics National Research University, \\ 11, Pokrovsky bul., Moscow, 109028, Russian Federation \\ ${ }^{4}$ Kazan Federal University, \\ 18, ul. Kremlevskaya, Kazan, 420008, Russian Federation
}

For citation: Tsyplenkov, A. S., Ivanova, N. N., Botavin, D. V., Kuznetsova, Yu. S., Golosov, V. N. (2021). Hydro-meteorological preconditions and geomorphological consequences of extreme flood in the small river basin in the wet subtropical zone (the Tsanyk River case study, Sochi region). Vestnik of Saint Petersburg University. Earth Sciences, 66 (1), 144-166. https://doi.org/10.21638/spbu07.2021.109 (In Russian)

The overall increase in precipitation and the frequency of extreme rainfall is confirmed by several meteorological observations both on the Black Sea coast of the Caucasus, and in other regions with similar environmental conditions. In this context, research on the drivers of an extreme meteorological event becoming a severe flood and an extreme geomorphological (erosion) event becomes especially important. The article analyses the factors contributing to the development of a flash flood on the watershed of the river Tsanyk (Greater Sochi area) and estimates its geomorphological impact. Analysis of the hydrologic-meteorological situation during the Tsanyk flood on 7-9 September 2018 and in the previous period showed that the event is unique for the investigated watershed from the hydrologic perspective. After a prolonged period without precipitation, the rainfall on 7-8 September resulted in a flash flood with a rapid water level rise (117 $\mathrm{cm}$ in $40 \mathrm{~min}$.). We determined the rates and volumes of channel erosion based on a repeated survey of the channel section, estimation of the speed and length of the banks being flushed out - composed of loose sediments and bedrock - using the pin method. The amount of erosion on the banks composed of loosened sediments was on average 2-3 times higher than on the flysch banks. At the same time, the material export for one erosion event in September 2018 is comparable to (or even exceeds) the total amount of bank erosion for a year, previously identified based on stationary observations.

Keywords: sediment yield, flash flood, extreme erosion event, subtropics.

\section{References}

Alekseevskii, N.I., Magritskii, D. V., Koltermann, P. K., Toropov, P. A., Shkol'nyi, D. I. and Beliakova, P.A. (2016). Inundations on the Black Sea coast of Krasnodar krai. Vodnye resursy, 43 (1), 3-17. https://doi. org/10.7868/S032105961601003X (In Russian)

Balian, G. A. and Ramenskii, L. G. (1954). About the simplest ways to measure soil erosion and how to determine its creepiness. Pochvovedenie, (2), 75-81. (In Russian)

Berkovich, K. M., Golosov, V.N., Zorina, E. F., Korotaev, V. N., Litvin, L. F. and Chalov, R. S. (2005). Erosive and channel systems: structure and evolution under natural and anthropogenic changes. Vestnik Moskovskogo universiteta. Seriia 5. Geografiia, (2), 61-67. (In Russian) 
Bolgov, M. V. and Osipova, N. V. (2014). Joint analysis of maximum runoff and precipitation data in the Adagum River Basin. Vodnoe khoziaistvo Rossii: problemy, tekhnologii, upravlenie, (3), 5-15. (In Russian)

Bondyrev, I. V. and Tsereteli, E. D. (2007). Catastrophic mud flows in the south of the Caucasus. In: Proceedings of the International scientific conference "Dangerous Natural and Man-Caused Processes on the Mountaneous and Foothill Territories of North Caucasus". Vladikavkaz, 20-22 September 2007. Vladikavkaz: VNTs RAN i RSO-A Publ., 108-115. (In Russian)

Bulygina, O. N., Razuvaev, V.N., Korshunova, N.N. and Shvets, N.V. (2020). Avtomatizirovannaia informatsionnaia sistema obrabotki rezhimnoi informatsii (AISORI). [online] Available at: http://aisori-m. meteo.ru/waisori/ [Accessed Feb. 26, 2021]. (In Russian)

Coppus, R. and Imeson, A.C. (2002). Extreme events controlling erosion and sediment transport in a semi-arid sub-andean valley. Earth Surface Processes and Landforms, 27 (13), 1365-1375. https://doi. org/10.1002/esp. 435

emercit.ru. (n.d.). Emercit monitoring system. [online] Available at: http://emercit.ru/map/ [Accessed Feb.19, 2021].

Gaume, E. et al. (2009). A compilation of data on European flash floods. Journal of Hydrology, 367 (1-2), 70-78. https://doi.org/10.1016/j.jhydrol.2008.12.028

Golosov, V.N., Della Seta, M., Azhigirov, A. A., Kuznetsova, Yu. S., Del Monte, M., Fredi, P., Lupia Palmieri, E. and Grigoreva, T. M. (2012). Anthropogenic impact on exogenous processes in low mountains of subtropics. Geomorfologiia, (2), 7-17. https://doi.org/10.15356/0435-4281-2012-2-7-17 (In Russian)

Goudie, A., Lewin, J., Richards, K., Anderson, M., Burt, T., Whalley, B. and Worsley, P. (1990). Geomorphological Techniques. London: Unwin Hyman.

Holm, S. (1979). A Simple Sequentially Rejective Multiple Test Procedure. Scandinavian Journal of Statistics, $6(2), 65-70$.

Ivanova, N. N., Golosov, V. N., Tsyplenkov, A. S., Kuznetsova, Yu. S. and Botavin, D. V. (2018). Sources of the basin component of the sediment yield on the small river in the foothill-lowland zone of the Black sea coast of the Caucasus (using the example of the Tsanyk river). Inzhenernye izyskaniia, 12 (7-8), 62-76. https://doi.org/10.25296/1997-8650-2018-12-7-8-62-74 (In Russian)

Khristoforov, A. V., Iumina, N. M. and Beliakova, P. A. (2015). Forecast of flood runoff in the rivers of the Caucasus Black Sea coast in one day's perspective. Vestnik Moskovskogo universiteta. Seriia 5. Geografiia, (3), 50-57. (In Russian)

Klimenko, D.E. (2017). The experience of applying a one-sided truncated log-normal distribution to calculations of the maximum run-off of rain floods in small rivers. Inzhenernye izyskaniia, (10), 66-71. https://doi.org/10.25296/1997-8650-2017-10-66-71 (In Russian)

Klimenko, D. E., Cherepanova, E. S., Gabova, L. V. and Shchapova, I. V. (2018). Comparative statistical analysis of survey data of gauges and pluviographs for assessment of characteristics of flood-forming precipitation in the Urals territory. Meteorologiia i gidrologiia, (8), 91-99. (In Russian)

Koronkevich, N.I., Barabanova, E.A., Bumakova, A. F., Zaitseva, I.S. and Malik, L. K. (2005). Extreme Hydrologcal Events. Izvestiia Rossiiskoi akademii nauk. Seriia geograficheskaia, (2), 45-57. (In Russian)

Koronkevich, N.I., Barabanova, E. A. and Zaitseva, I.S. (2010). Hydrological extremes. Moscow: MediaPRESS Publ. (In Russian)

Krasnov, S. F. (1980). Soil erosion research using the artificial sprinkling method. In: Eroziia pochv i osvoenie sklonovykh zemel'v subtropicheskoi zone RSFSR. Nauchn. trudy NIGSiTs, T. 27. Sochi: NIIGSiTs Publ., 97-104. (In Russian)

Kuznetsova, Yu. S., Golosov, V.N. and Kuksina, L.V. (2015). Flash floods: formation factors, diffusion and forecasting techniques. In: Problemy prognozirovaniia chrezvychainykh situatsii. Kruglyi stol. 17 September 2015. Doklady i vystupleniia. Moscow: FKU Tsentr "Antistikhiia” MChS Rossii Publ., 207-214. (In Russian)

Kuznetsova, Yu., Golosov, V., Tsyplenkov, A. and Ivanova, N. (2019). Quantifying channel bank erosion of a small mountain river in Russian wet subtropics using erosion pins. Proc. Int. Assoc. Hydrol. Sci., 381, 79-86. https://doi.org/10.5194/piahs-381-79-2019

Magritskii, D. V. (2014). Spatial-temporal parameters of floods at the Black sea coast of the Russian Federation. Vestnik Moskovskogo universiteta. Seriia 5. Geografiia, (6), 39-47. (In Russian)

Mal'neva, I. V. and Kononova, N.K. (2012). Mudflow activity in Russia and neighboring countries in the XXI century. Georisk, (4), 48-54. (In Russian) 
Marchi, L., Borga, M., Preciso, E. and Gaume, E. (2010). Characterisation of selected extreme flash floods in Europe and implications for flood risk management. Journal of Hydrology, 394 (1-2), 118-133. https:// doi.org/10.1016/j.jhydrol.2010.07.017

Methodological recommendations for determining the calculated hydrological characteristics in the presence of hydrometric observations data. (2005). St. Petersburg: GGI Publ. (In Russian)

Methodological recommendations for determining the calculated hydrological characteristics in the absence of hydrometric observations data. (2009). St. Petersburg: Nestor-Istoriia Publ. (In Russian)

Pendergrass, A. G. and Knutti, R. (2018). The uneven nature of daily precipitation and its change. Geophysical Research Letters, 45 (21), 11,980-11,988. https://doi.org/10.1029/2018GL080298

Poliakov, B. V. (1946). Hydrological Analysis and Calculations: A Manual. Leningrad: Gidrometeoizdat Publ. (In Russian)

Renard, K. G., Foster, G. R., Weesies, G. A., McCool, D. K. and Yoder, D. C. (1997). Predicting soil erosion by water: a guide to conservation planning with the Revised Universal Soil Loss Equation (RUSLE). In: Agricultural Handbook No. 703, 65-100.

Rets, E. and Kireeva, M. (2010). Hazardous hydrological processes in mountainous areas under the impact of recent climate change: case study of Terek River basin. In: Global Change: Facing Risks and Threats to Water Resources. IAHS Publ., 126-134.

rp5.ru. (2020). Weather timetable. [online] Available at: https://rp5.ru/ [Accessed Feb. 19, 2021].

Semenov, V. A. and Korshunov, A. A. (2008). Zoning of the Russian territory at risk of high flooding due to climate change. Ispol'zovanie i okhrana prirodnykh resursov $v$ Rossii, (5), 58-61. (In Russian)

Shnyparkov, A. L., Koltermann, K. P., Seliverstov, Iu. G., Sokratov, S. A. and Perov, V. F. (2012). Debris flows risk in the Caucasian black sea coastal zone. Georisk, (4), 20-25. (In Russian)

Sloto, R. A. and Crouse, M.Y. (1996). Hysep: a computer program for streamflow hydrograph separation and analysis. U. S. Geological Survey Water-Resources Investigations Report 96-4040.

Špitalar, M., Gourley, J. J., Lutoff, C., Kirstetter, P.-E., Brilly, M. and Carr, N. (2014). Analysis of flash flood parameters and human impacts in the US from 2006 to 2012. Journal of Hydrology, 519, 863-870. https://doi.org/10.1016/j.jhydrol.2014.07.004

Tananaev, N. I. (2012). Hysteresis effect on seasonal variability in the ratio of flow to turbidity of water in the rivers of the cryolithic zone of Siberia and the Far East. Vodnye resursy, (6), 598-607. (In Russian)

Tang, C., van Asch, T. W. J., Chang, M., Chen, G. Q., Zhao, X. H. and Huang, X. C. (2012). Catastrophic debris flows on 13 August 2010 in the Qingping area, southwestern China: The combined effects of a strong earthquake and subsequent rainstorms. Geomorphology, 139-140, 559-576. https://doi.org/10.1016/j. geomorph.2011.12.021

Tsyplenkov, A.S., Golosov, V.N. and Kuksina, L. V. (2017). Assessment of basin component of suspended sediment yield generated due to rainfall events at small rivers in wet and dry subtropics. Engineering survey, (9), 54-65. https://doi.org/10.25296/1997-8650-2017-9-54-65 (In Russian)

Vishnevskaia, I.A., Desinov, L.V., Dolgov, S.V., Koronkevich, N.I., Shaporenko, S.I., Kireeva, M. B., Frolova, N. L., Rets, E. P. and Golubchikov, S. N. (2016). Geographical and Hydrological Assessment of Floods in the Russian Black Sea Region. Izvestiia Rossiiskoi akademii nauk. Seriia geograficheskaia, (1), 131-146. https://doi.org/10.15356/0373-2444-2016-1-131-146 (In Russian)

Zeileis, A. and Grothendieck, G. (2005). zoo: S3 Infrastructure for Regular and Irregular Time Series. Journal of Statistical Software, 14 (6). https://doi.org/10.18637/jss.v014.i06

Received: May 22, 2020

Accepted: December 14, 2020

Contact information:

Anatoly S. Tsyplenkov - atsyplenkov@gmail.com

Nadezda N.Ivanova — nadine_iv@mail.ru

Dmitry V.Botavin — dmitry.botavin@gmail.com

Yulia S. Kuznetsova - kuzyulia@gmail.com

Valentin N.Golosov — gollossov@gmail.com 